\title{
Music Education in the Thematic Lessons for Elementary Schools
}

\author{
Ardipal $^{1}$ \\ ${ }^{I}$ FacultyofLanguagesandArts, Universitas NegeriPadang, Padang, West Sumatra, Indonesia \\ Corresponding author: $ه($ email), ardipal@fbs.unp.ac.id
}

\begin{abstract}
Rarely are researches discussing about a theme-based music education intended for elementary school students found. The research on this topic, nonetheless, is particularly important to reveal whether or not the practice currently implemented by primary school teachers have met the principles of effective thematic lesson. This research is purposed to figure out the themes and songs along with dominant teaching method and teaching media utilized by teachers in the theme-based lessons. This research employs a mixed method research design. The results yielded by this research show that only a quarter of teachers $(25 \%)$ have attempted to teach the entire lesson themes embedded in the Curriculum of 2013. Even though there are few irrelevant songs that teachers integrated into the lessons, majority of them have adhered to the lesson themes mandated by the curriculum. Additionally, cooperative learning is accounted for $57.9 \%$ of preferred teaching method by the teachers, while an individual learning (lecture) makes up the smallest proportion of teaching method used (12.3\%). As for the teaching media employed, the three- top selected teaching media include book (69.73\%), hand phone (60.5\%), and computer (57.9\%). Finally, a number of suggestions are addressed to the education practitioners and other related stakeholders about a more rigorous execution of a theme-based music education for primary schools.
\end{abstract}

Keywords: thematic lesson, cooperative learning, teaching media, teaching method, elementary schools

\section{INTRODUCTION}

Due to its significant function as a medium to express beauty, art education is nominated as one of the compulsory subjects in the curriculum at all levels starting from preschool to secondary education. At elementary school level, the students are only required to perform some very simple artistic skills such as drawing (visual art) and singing (sound art). In order to achieve the goals of primary education, a thematic lesson-a lesson administered accordingly to the lesson themes - is enforced to primary and secondary education. Trianto [1] states that a thematic lesson is a range of meaningful as well as entertaining activities for students to equip them with effective learning experience. There are 3 fundamental factors needed to be taken into account in succeeding the thematic lesson practice: the characteristics of primary school education, the characteristics of students' psychology, and teacher's understanding on children's culture [2]. Assessing the implementation of theme-based music education necessarily means analyzing the fulfillment of the aforementioned components.

Although there are a number of advantages resulted from a thematic lesson, the drawbacks come in many forms as well. Some of the shortcomings are 1) teacher's low capacity in integrating the appropriate nursery rhymes with the lesson themes, 2) fragmented learning approaches instead of scientific approaches as suggested by the Curriculum of 2013 , 3) lesson materials do not adhere to student's local culture, 4) the use of subject-based teaching as opposed to integrated teaching, and others [3]. In line with Pudjiastuti's idea, Sinaga [4] conveys that other issues on the thematic lesson are teachers' considerable low expertise in reading the song notations, and inadequate facilities of music learning. These problems may slowdown the progress of knowledge and skills transfer from teachers to students which eventually delay the materialization of thematic learning principles of "learning by doing" and "learning by playing" embedded in the Curriculum of 2013.

The students' needs towards an interconnected and simultaneous learning experience is the rationale beyond the thematic lesson implementation [5] because after accomplishing their formal education at schools, students will eventually deal with holistic views in the environment they associate with. Hence, integrated learning apparently is the method that students demand from school. In addition, he argues that learning occurs best at the time students are given the opportunity to count, measure, feel, and touch the objects they are studying. Thematic lessons whose approach is to endow them with actual and concrete 
experience will be much more likely to provide students with the best learning experience. Another motive of thematic lesson enforcement is lowering the number of school children who abandon schools because of tedious learning activities in the classroom [6]. Students mostly quit schools for teachers fail to satisfy their desire on enjoyable learning activities. A theme-based lesson offers them synchronized, relaxing, and integrated learning experience, thus it is projected to resolve the problem.

As far as the teaching method concerns, thematic lessons have several options of methods to be practiced. Amri [7] lists 9 teaching methods below:

a. Cooperative learning.

b. Picture and picture.

c. Cooperative Integrated Reading and Composition (CIRC).

d. Problem solving-based learning.

e. Guided invention learning model.

f. Direct learning.

g. Missouri Mathematics Projects (MMP).

h. Problem Posing Learning.

i. Contextual learning.

Similar to Amri's opinions, Ardipal [8] lists several teaching modes appropriate for teaching art education including lecture, cooperative learning, question and answer, and discussion. This research is proposed to identify lesson themes taught by teachers at primary schools and the types of nursery rhymes incorporated in the lesson. Besides, the dominant teaching method and teaching media utilized by teachers are also examined through this research. It is anticipated that this research will disclose the most effective model of thematic lesson integrated with nursery rhymes for elementary school level. When the lesson themes, nursery rhymes, mostly used teaching method and teaching media have been discovered, the concept of an ideal thematic music teaching can be established to primary schools.

Previous researches on the issue of music education carried out within the thematic lessons for elementary schools have been focusing on the significance and appropriateness of thematic music for students in the elementary schools. The relevance of music education on achieving the early childhood education's competence was studied by Wicaksono [9], while the importance of teaching music to enhance the preschool students' cognitive development was scrutinized by Nasution [10]. Wijayanti, Choiril, and Wahyuningsih [11] as well as Arostiyani [12] examined how music positively contributes in building preschool students' good characters. The role of music education in improving student's skills in communicating and expressing their ideas was reported by Suheri [13]. However, researches on the practicality of thematic music education for elementary schools, specifically in West Sumatra are yet to be executed. As a consequence, the investigation on the completion of thematic music education is necessary to uncover a better mechanism and strategy for running the program in the future.

Lesson themes taught in the classrooms, teaching methods, and teaching media commonly selected by primary school teachers are the main problems discussed in this paper. This paper is consigned to discover which lesson themes are taught by teachers in the primary education, how teachers perform the thematic music education, and which teaching media is dominantly utilized. Lastly, this research is planned to generate the concept of a more inclusive and effective thematic music education at primary school level. A couple of recommendations are addressed to pertaining stakeholders in this matter by the end of this paper.

\section{METHODS}

\section{Research Design}

This research employed a mix-method design. In other words, both qualitative and quantitative aspects of approaches are partially or wholly utilized [14] in order to retain a comprehensive understanding on a particular phenomenon or issue [15] and [16]. With this method is put in place, a reliable and valid research result may be obtained through a multi-level analysis [17].

\section{Population and Sampling Procedure}

Elementary school teachers of West Sumatra who teach music education to their students were the populations of this study. As for the sampling, random sampling was used to probe the issue of music education in the thematic lesson. A random sampling is a technique to select the research participants aimed at ensuring the individuals to effectively represent the whole population [18]. Since this research was intended to examine a quite large population, preventing bias in data analysis should be the prerequisite to produce a reliable research result. Hence, a random sampling is best used as the sampling strategy.

\section{Research Participants}

The participants in this study were 75 teachers of elementary schools spread in 9 regions in West Sumatra including Padang, Bukittinggi, Padang Panjang, Sawahlunto, Solok, Solok Selatan, Payakumbuh, Sijunjung, and Tanah Datar. In order to obtain the relevant research participants, the researcher indicated the respondent criteria along with the questionnaire link when distributing it online and offline. Once the respondents returned the questionnaire or filled it through the link provided online, all teachers were found to be eligible respondents. However, 4 teachers were identified skipping all the open-ended questions, hence those 4 data were excluded from the data analysis. Nevertheless, the data were still valid as they were collected from 71 respondents. The minimum number of respondent according to Dörnyei [19] are 30 people, thus the collected data have reached the standard amount of data for a good research.

Furthermore, the respondent's service duration and the latest education level they had were required in the questionnaire. Various length of service was seen in the respondent's response in the range of less than one year to more than five years. Those who had served in the 
elementary school for less than a year, one year, 2- 5 years, and more than 5 years were counted as much $34.2 \%, 6.6 \%$, $17.1 \%$, and $42.1 \%$ respectively. This information was intended to analyze how the teachers' teaching experience affected the student's learning experience on the thematic lesson. Teacher's education background was asked with the purpose of figuring out whether their academic qualifications are relevant to the music education lesson. Of a total 71 respondents, $\mathrm{xx} \%$ of them demonstrated that they did not possess the pertinent education background to administer the thematic music lesson. A majority of teachers $(85 \%)$ revealed that they were holding a degree from Elementary Teacher Education instead of a Music Education background.

\section{Data Collection Instruments Questionnaire}

Both questionnaire and interview were utilized in this study. Provided that this research pioneered the study on thematic music education in elementary schools, the questionnaire utilized was the researcher-designed questionnaire. The items included in the questionnaire were created based on the information catered in the literature review in order to produce well-structured questionnaire [18]. The failure in preparing a questionnaire congruent to the key issues highlighted in the literature study may jeopardize the reliability and validity of the research.

In regards to the details of the questionnaire, it consisted of 19 close-ended items (i.e. Likert scales), 12 semi close-ended/check list items, and 4 open-ended questions. To be specific, the first-three questions (i.e. semi close-ended questions) were purposed at clarifying both research questions about the lesson themes in the thematic lesson. The questions were then followed by the items intended to disclose the information about factors hampering teacher's teaching performance. These items contained several sub-categories such as teacher's preference in teaching media, teaching methods (2 questions), teaching strategies (3 questions), and internet connection availability (4 questions). In addition, the information about the thematic lessons pertinent to Child Culture (12 questions) was also asked as the basis to analyze the music lesson efficacy later on. Last but not least, the items probing the teachers' overall perspectives towards thematic music education were also included (2 questions).

Open-ended questions are encouraged to be employed in the questionnaire. The rationale beyond this is that the data collected through close-ended questions, which oftentimes are in forms of quantitative data, tend to be inadequate to fulfill the demand towards a thorough data analysis. Dörnyei [19] clarifies that open-ended items could significantly enrich the information which has already been served by the close-ended questions. Hence, this type of question was incorporated into the questionnaire.

\section{Interview}

An interview was conducted to explore teachers' perspectives towards the thematic music learning at elementary school. A part-structured interview was adopted as another data collection tool in this research. This interviewing typology was adopted for the sake of ensuring the fulfillment of researcher's main intention while granting a chance for the interviewees to elicit their thoughts on peculiar issues addressed in the interview process at the same time as to retain "both breadth and depth in the datasets" [20]. In accordance to Dörnyei's [21] and Cohen's et al. [22] accounts on administering a part- structured interview, a predetermined openended interview questions i.e. protocol were asked to the interviewees with no regards to the order of the prepared interview questions. The number of questions comprised in the interview protocol was 10 questions dismantling 3 key areas (see Appendix).

\section{Ethical Consideration}

The ethical concern was ensured prior to the data collection process. In doing so, the information about this research together with the consent form was provided in the initial page of the questionnaire. The respondents were informed that participation in this research was voluntary, thus they may decide to terminate their involvement at any time Furthermore, in the interview stage, the participants' consent to be recorded was also corroborated. Therefore, their names and the school institution where they are working in were obscured in the research report.

\section{Data Collection Procedure}

Prior to distributing the questionnaire to a large number of respondents, it was piloted to 6 people, a minimum number of respondents in piloting the questionnaire according to Anderson [23]. When returned, a couple of items needed to be revised and added to the questionnaire. The previous questionnaire consisted of 24 questions, and after being edited it comprised 36 items with 12 added questions were in form of Likert scales. An estimated of 20-25 minutes was the duration of time needed to fill in the questionnaire. Google form is the tool by which the questionnaire was created, and it was distributed through online platforms i.e. WhatsApp, Instagram, and Facebook to potential research participants.

As far as the response rate shown by the respondents, the graphic presented a reasonably low participation from the targeted participants. Over the course of more than three weeks, there were only 75 participants taking a part in this survey. Nevertheless, almost $95 \%$ of those respondents were unanimous to the researcher.

Table 1 informs that almost all lesson themes mandated by the Curriculum of 2013 has been taught by elementary school teachers in West Sumatra. The survey shows that $34.8 \%$ teachers teach the whole lesson themes with $15.9 \%$ of them teach the second. 
Table 1. Nursery rhymes and lesson themes

\begin{tabular}{|c|c|c|}
\hline No. & Nursery Rhymes & $\begin{array}{l}\text { Lesson } \\
\text { Themes }\end{array}$ \\
\hline 1 & $\begin{array}{llr}\text { Menanam } & \text { Jagung, } & \text { Paman } \\
\text { Datang, } & \text { Bareh } & \text { Solok, } \\
\text { Kebunku } & & \\
\end{array}$ & Plants \\
\hline 2 & $\begin{array}{l}\text { Terima Kasih Sahabat, } \\
\text { Peramah dan Sopan, Ayo } \\
\text { Makan Bersama, Sebelum } \\
\text { Kita Makan }\end{array}$ & $\begin{array}{l}\text { My Activities, } \\
\text { Health }\end{array}$ \\
\hline 3 & 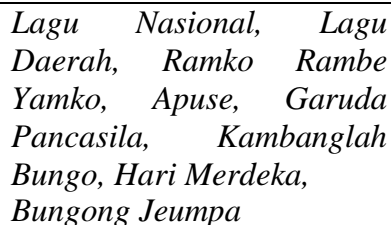 & $\begin{array}{l}\text { My Homeland, } \\
\text { Tolerance }\end{array}$ \\
\hline 4 & $\begin{array}{l}\text { Topi Saya Bundar, Dua } \\
\text { Mata Saya, Aku Anak Soleh, } \\
\text { Nama-nama Jari, Kepala } \\
\text { Pundak, Gigi }\end{array}$ & My Self \\
\hline 5 & $\begin{array}{l}\text { Kasih Ibu, Satu-satu Sayang } \\
\text { Ibu, Ruri Abangku }\end{array}$ & My Family \\
\hline 6 & $\begin{array}{l}\text { Pelangi, Tik-tik Hujan, } \\
\text { Ambilkan Bulan, Naik-naik } \\
\text { ke Puncak Gunung }\end{array}$ & Nature \\
\hline 7 & $\begin{array}{l}\text { Kupu-kupu yang Lucu, } \\
\text { Burung Kutilang, Injit-injit } \\
\text { Semut, Banyak Nyamuk di } \\
\text { Rumahku, Kunang-kunang, } \\
\text { Anak Ayam }\end{array}$ & Animals \\
\hline 8 & $\begin{array}{l}\text { Naik Delman, Naik Becak, } \\
\text { Naik Kereta Api, Berdayung }\end{array}$ & $\begin{array}{l}\text { Safety at } \\
\text { Home and } \\
\text { Road }\end{array}$ \\
\hline 9 & Saya Suka Sate & My hobbies \\
\hline 10 & $\begin{array}{l}\text { Jangan Buang Sampah } \\
\text { Sembarangan }\end{array}$ & $\begin{array}{l}\text { Environmental } \\
\text { Awareness }\end{array}$ \\
\hline 11 & Tepuk Pramuka & Scouts \\
\hline 12 & Mariam Tomong & $\begin{array}{l}\text { Appreciation } \\
\text { towards } \\
\text { Heroes/ } \\
\text { Heroins } \\
\end{array}$ \\
\hline 13 & $\begin{array}{l}\text { Layang-layang,Siapa } \\
\text { Namamu, Anak Gembala, } \\
\text { Tepuk Ame-ame, Balonku, } \\
\text { Libur Telah Tiba, Lagu } \\
\text { Anak Berbahasa Inggris, } \\
\text { Lagu Berbahasa Arab, } \\
\text { Puasa }\end{array}$ & $\begin{array}{l}\text { Not } \\
\text { Categorized }\end{array}$ \\
\hline
\end{tabular}

\section{RESULTS AND DISCUSSION}

Music Education in the Theme-Based Lessons at Elementary School

Music has been highly contributing towards the development of children's cognitive and emotional capacity. Besides, the noteworthy effect of learning music can be also seen in student's increased creativity level. Nonetheless, teachers should try to abide to lesson themes that the Curriculum of 2013 has been stipulated to teach. However, teachers tend to adjust the themes with the student's needs whenever it is necessary. As to simplify the analysis of themes taught in the elementary school, the researcher categorizes the themes into 2 groups: lower grade (1-3) and higher grade (4-6). The survey intended to seek out the proportion of lesson themes administered by elementary school teachers presents the following information: theme, My Hobbies. However, there are very few teachers who teach the rest of the lesson themes; the proportion ranges from $2.9 \%$ to $13 \%$ only. In other words, there are only a third of elementary school teachers who have delivered the entire lesson themes through songs. Meanwhile, other lesson themes are still left abandoned without nursery rhymes during the classroom activities. The vast majority of teachers taught the themes of My Self and My Hobbies in the lower class, both accounted for $13.2 \%$. Similarly, the most preferred theme taught in higher grade are also My Hobbies and My Self with each theme was delivered by $15.9 \%$ and $13 \%$ by chronological order. As for the nursery rhymes incorporated into the lesson themes, a list of songs is found in the survey as follow:

Table 2. Theme of songs taught at schools

\begin{tabular}{|c|c|c|c|}
\hline No. & Themes & Taught & $\%$ \\
\hline A. & Lower Grade (1-3) & & \\
\hline 1 & My Self & $\mathrm{v}$ & 39.5 \\
\hline 2 & My Hobbies & $\mathrm{V}$ & 13.2 \\
\hline 3 & My Activities & $\mathrm{V}$ & 13.2 \\
\hline 4 & My Family & $\mathrm{V}$ & 11.8 \\
\hline 5 & My Experience & $\mathrm{V}$ & 7.9 \\
\hline 6 & My Environment & $\mathrm{V}$ & 5.3 \\
\hline 7 & $\begin{array}{l}\text { Plants, Animals, and } \\
\text { Things }\end{array}$ & $\mathrm{V}$ & 6.6 \\
\hline 8 & Nature & $\mathrm{v}$ & 9.2 \\
\hline 9 & $\begin{array}{l}\text { Safety at Home and } \\
\text { Road }\end{array}$ & $\mathrm{v}$ & 9.2 \\
\hline 10 & Technology & $\mathrm{v}$ & 1.3 \\
\hline 11 & Scouts & $\mathrm{V}$ & 1.3 \\
\hline B. & Higher Grade (4-6) & & \\
\hline 1 & Tolerance & $\mathrm{v}$ & 1.3 \\
\hline 2 & $\begin{array}{l}\text { Environmental } \\
\text { Awareness }\end{array}$ & $\mathrm{v}$ & 34.8 \\
\hline 3 & $\begin{array}{l}\text { Occupation a } \\
\text { nd } \\
\text { Entrepreneurship }\end{array}$ & $\mathrm{v}$ & 13 \\
\hline 4 & My Homeland & $\mathrm{V}$ & 15.9 \\
\hline 5 & $\begin{array}{l}\text { Appreciation for the } \\
\text { Heroes/Heroines }\end{array}$ & $\mathrm{v}$ & 7.2 \\
\hline 6 & My Dreams & $\mathrm{v}$ & 2.9 \\
\hline 7 & Health & $\mathrm{V}$ & 2.9 \\
\hline 8 & My Self & $\mathrm{V}$ & 5.8 \\
\hline 9 & Globalization & $\mathrm{V}$ & 5.8 \\
\hline 10 & $\begin{array}{ll}\text { Inventors and } \\
\text { Figures }\end{array}$ & $\mathrm{v}$ & 8.7 \\
\hline
\end{tabular}

Based on the survey conducted by the researcher towards elementary school teachers in West Sumatra, twelve categories of songs are coded with one category is in no relation to any lesson themes for elementary school. 
The rest of eleven categories are pertaining to majority of lesson themes for both lower and higher grades. However, some themes are still taught without employing nursery rhymes such as Technology, Occupation and Entrepreneurship, Globalization, and My Dreams. Some teachers admit that they find it difficult to create song lyrics pertaining to those lesson themes. Others reason that other teaching media are more effective to deliver the respected themes than songs are. It implies that songs are not always the most preferable teaching medium, but it depends on the goals of the lesson, the students' characteristic, and the skills that teachers aim to teach to the students.

Songs incorporated into the thematic lessons apparently comprise cultural and religious values necessary for shaping students' good demeanor and habits. Sebelum Kita Makan, Peramah dan Sopan, and Jangan Buang Sampah Sembarangan are instances of songs useful to teach students the acceptable customs in society. Nationalism in the modest way is also taught through the nursery rhymes as seen in the songs of Garuda Pancasila and Hari Merdeka. Cultural values are reflected in traditional songs such as Apuse, Bungong Jeumpa, and Yamko Rambe Yamko, while religious values are embedded in songs like Aku Anak Soleh dan Puasa. Although many songs are interrelated to the lesson themes mandated by the Curriculum of 2013, several songs are identified to be out of categories.

\section{How Teachers Deliver the Thematic Music Lesson for Elementary School Students}

Approaches to thematic music teaching may come in various kinds. When an approach has been systematically operated, the respected approach may be called a teaching method. A number of teaching methods can be performed by teachers to administer the thematic lessons to elementary school students. Ardipal [24] mentions that a teaching method must be relevant to the learning goals, learning principles, lesson material types, and student's characteristics. To find out which dominant teaching method is employed in the classroom activities, a survey was conducted yielding the information in the diagram below.

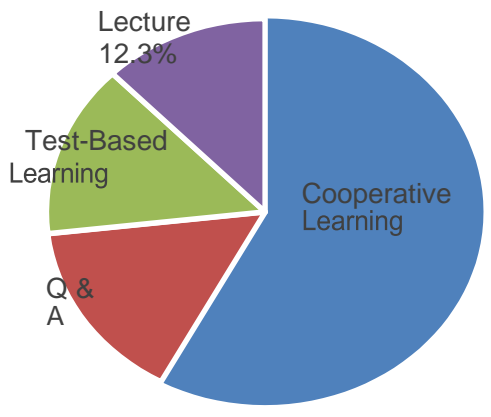

Figure 1. Teaching Methods Implemented by Teachers at Elementary Schools in West Sumatra

As depicted in the chart above, there were four kinds of teaching methods generally used by school teachers to teach the thematic music lesson in West
Sumatra including cooperative learning, question and answer, test-based learning, and lecture. The dominant teaching method used is the cooperative learning (57.9\%) as opposed to the least method used of lecture $(12.3 \%)$. According to the respondents, cooperative learning facilitates the students to engage with the classroom activities better than any other types of teaching method. Moreover, student's creativity, team-work, critical thinking, and communicative skills are also sharpened through learning in group due to opportunities for students to share their thoughts and perspectives with other students in their group. Partnership for $21^{\text {st }}$ Century Learning (LP21) mentions that there are 4 skills urgently needed to strive in the globalization era: collaboration, creativity, critical thinking, and communication (P21 Framework, n.d.). Cooperative learning equips students with these four sets of skill when it is implemented in the teaching and learning process.

Lecture, on the other hand, poses very limited chances for students to exchange ideas with their peers resulting in student's poor creative ideas, ability to work in team, communication, and ability to think critically. Employed by $12.3 \%$ of respondents, this type of teaching method puts teachers at the center of classroom activities, while students become passive audience. Art education is aimed at forming the students' understanding upon both theoretical as well as practical concepts. Hence, the students have to be proficient not only in the mastery of abstract idea of arts, but also in the expression of their idea. Given the fact that lecture only emphasizes in the mastery of abstract artistic conception, it barely enables students to be skilful at making use of their artistic skills into a concrete art work. Finally, this what constitutes knowledgeable students in arts yet unable of producing art work.

Both of the question and answer as well as the testbased learning are moderately preferred by teachers, constituting approximately $30 \%$ of the whole respondents who took the survey. A question and answer teaching method involves factual information, learning concept, principles, and art procedures either by teachers to students or vice versa [25]. Respondents acknowledge that this teaching method encourages students to actively participate in the classroom activities. It is also the simplest strategy to disseminate information and facts to the students. A testbased teaching mode, on the other hand, drives students to evaluate what they have learned and comprehended from learning activities. The evaluation is purposeful for the improvement of students' competence and skills in the thematic music lesson. This teaching method is reckoned as beneficial by respondents as it discloses the effectiveness as well as efficiency of teacher's teaching strategies, lesson materials, and teaching media. A better practice can be implemented based on the evaluation in the future.

Teaching Media Utilized by Elementary School Teachers and How They Have Worked in the Classroom Activities

Utilizing media in the teaching and learning activities may simplify the process of transferring the 
information, concepts, and principles of thematic music from teachers to students or vice versa. Quoting Ardipal [24], music education shall be administered by equipping students with music experience along with all types of sounds. For this reason, a special music classroom is needed to conduct music lessons as to prevent disturbance towards students in other classes. Various music instruments and/ or other medium supporting the learning activities are necessary to be made available. Aforementioned facilities unfortunately are yet to be fulfilled by the government in West Sumatran elementary schools. Referring to the survey, more than half of total respondents assert that there is very finite number of music learning facilities at their schools. Moreover, when the respondents are asked what improvement they are looking for, around a third of them mention that facilities in learning music are what they expect to have.

After conducting a survey towards elementary schools in West Sumatra, a number of electronic and nonelectronic teaching media are discovered such as book, hand phone, magazine, radio, tape recorder, computer, laptop, speaker, and projector. They are grouped into portable nonelectronic, portable electronic, and non-portable electronic devices. Non-portable media such as computer are initially thought to be less utilized by teachers. However, it is revealed that this type of media is among the top 3 most preferred one. Certain sorts of portable media in form of both electronic (i.e. hand phone, radio, tape recorder, laptop, and speaker) and non-electronic (i.e. book and magazine) are likely to be used by the teachers in the classroom to teach thematic music. Portable non-electronic media used frequently is book $(69.7 \%)$, while the portable electronic one is hand phone $(60.5 \%)$. Computer, the non-portable electronic device is utilized by $57.9 \%$ of elementary school teachers. Table 3 below shows the detailed information about varieties of teaching media and the proportion of teacher who utilize them.

Table 3. Varieties of teaching media

\begin{tabular}{|l|l|l|}
\hline Types of Media & Forms & \% \\
\hline Portable Non electronic & Book & 69.7 \\
\cline { 2 - 3 } & Magazine & 2.6 \\
\hline \multirow{4}{*}{ Portable electronic } & Mobile & 60.5 \\
\cline { 2 - 3 } & Radio & 3.9 \\
\cline { 2 - 3 } & Tape recorder & 19.7 \\
\cline { 2 - 3 } & Laptop & 3.9 \\
\cline { 2 - 3 } & Speaker & 2.6 \\
\hline Non portable devices & Computer & 57.9 \\
\cline { 2 - 3 } & Projector & 2.6 \\
\hline
\end{tabular}

Seeing the teacher's preference towards teaching media employed in teaching the thematic music in the diagram above, it can be safely stated that teachers do not always pick electronic or portable devices in the thematic music lesson. Synchronizing the teaching media with the student's characteristics, lesson materials, and lesson goals is what teachers decide, instead. Making the teaching media relevant to those factors above will result in a more meaningful learning experience to students; hence they are capable of reflecting their knowledge and expertise in arts in their everyday lives.
Apart from portable and non-portable as well as electronic and non-electronic media, the use of internet as another teaching media is also surveyed. As much as $59.2 \%$ respondents mention that they utilize the internet to deliver the thematic music lesson. Less than a half of the respondents admit that the internet quality is fair, but only $9.2 \%$ respondents mention that they use a very good internet connection. Beyond the network quality, the effectiveness of internet use in teaching thematic music is also examined. Despite the fact that the internet quality needs improvement, most of the respondents, precisely $87.6 \%$ of them, has a positive view towards the effectiveness of lesson delivery when internet is utilized. Time efficiency is the ultimate rationale for teachers in harnessing the internet for teaching the thematic music. With the utilization of internet, the lesson materials are within a single finger click and the contents are also educative, entertaining, and compatible to student's diverse needs.

Furthermore, forms of lesson materials promulgated by teachers when making use of the internet facility are also identified. Assorted types of lesson materials are adapted from the internet sources including videos, videos with song lyrics, sounds only (mp3), and song lyrics only in the word document. Videos are identified as the most frequently used materials accounted for $82.9 \%$, followed by music with song lyrics $(38.2 \%)$, mp3 (27.6\%). The least used forms of teaching materials retrieved from the internet are word document and karaoke, with each proportion are $6.6 \%$ and $7.9 \%$ respectively. Videos are visually more interesting for children, and they learn best when they are able to see, hear, and imitate the models shown in the video. Consequently, they become highly preferential to elementary school teachers. Word document and karaoke, on the contrary, appear to be monotonous and less engaging to most children. Thus, they are very unlikely to be selected as a teaching media by elementary school teachers in teaching the thematic music.

\section{How Government and Education Practitioners Should Run the Thematic Music Program for Elementary Schools}

Previous sub-topics have discussed about the lesson themes delivered utilizing nursery rhymes, teaching method prominently used, and teaching media commonly used by elementary school teachers. How an ideal thematic music lesson should be programmed in the elementary schools will be elaborated in this section. Recommendations will be addressed to the corresponding actors and stakeholders.

a. Government

Since the government plays a key role in the education policy making, they bear the responsibility of providing adequate learning facilities for music learning. More than $40 \%$ respondents admit that they are lacking of ample music learning facilities, whereas students require those facilities to enable them practicing the art concepts they have learned in the classroom. Practical application of thematic music will enhance student's artistic skills even better. Besides, teaching media which accommodates student's heterogeneous learning styles should be served by the government. When there are adequate teaching 
media at schools, teachers can make use of them to manage the classroom activities effectively. Moreover, government also has to equip elementary school teachers with training on teaching thematic lessons integral with nursery rhymes. Almost a half of the respondents (i.e. $44.7 \%$ ) state that they receive insufficient amount of training supervised by the government. Training insufficiency may cause teachers to be less competent in delivering the theme- based lessons through nursery rhymes. Students might suffer from teacher's low teaching proficiency. Consequently, government has the obligation to accommodate teachers with both learning facilities and intensive training on teaching thematic lessons using music.

Further, government also has to ascertain the quality of thematic music for elementary students by certifying the teachers as well as evaluate the program annually. A change in the National Curriculum is at discretion whenever the education programs embedded there are no longer relevant to the latest development nationally and globally. Skilful teachers are to be rewarded as a way to motivate others to perform better in the future. The appreciation program aimed at leveraging teacher's professionalism may boost the quality of music education for young learners.

\section{b. Teachers}

As for teachers in elementary schools, they are in charge of ensuring that the education program is executed accordingly to the curriculum applied currently. In this regards, teachers have to improve their teaching capacity and artistic skills through training or short courses offered either by the government or private institutions. The survey yields the proportion of teachers who struggle on reading the block and number notations (43.4\%), singing ability $(25 \%)$, and the competence of creating song lyrics correlated with the lesson themes $(40.8 \%)$. This indicates that teachers demand a sequence of training to improve their expertise on music and teaching. Alternatively, teachers may undertake a music course virtually or on campus learning in music academies such as Alison, Udemy, Wendy's Music, BerkleeX, and Dubspot. Awaiting for the government- administered training is oftentimes full of uncertainty and delays the process of effective thematic music learning.

Working more on the extensive lesson theme is also required from elementary school teachers in teaching the thematic music. A larger scope of lesson theme can promote a better creativity, knowledge, and skill for elementary school students. This occurs due to the opportunities for them to participate more actively in the classroom activities, bigger words repertoire of arts, and longer time to hone a more developed artistic skill. For instance, the theme of My Family can be specified into "My Father", "My Mother", etc. Extending the lesson themes will later augment the student's vocabularies, creativity, and critical thinking. These three skills are prerequisites for surviving the globalization era currently evolves in the entire parts of the globe.

\section{CONCLUSION}

Majority of lesson themes found to have been delivered through nursery rhymes by elementary school teachers in West Sumatra. Although a couple of songs appear to be irrelevant with the lesson themes mandated by the Curriculum of 2013, many of them have introduced contents pertaining to the main themes written in the curriculum. Additionally, the most preferable teaching media utilized by teachers in delivering the thematic music at elementary schools are books, hand phone, and computer. Internet has been used by some teachers, but a better network connection is required. Meanwhile, a cooperative learning is the method utilized dominantly by elementary school teachers in delivering the thematic music contents. Lastly, several suggestions are aimed for government as the policy makers and teachers as the education practitioners to elevate the quality of thematic music program at elementary schools in West Sumatra as well as in Indonesia as a whole. Those recommendations encompass the provision of music learning facilities, training for teachers in teaching the thematic music, enhancement on artistic skill and teaching capacity, and the extension of lesson themes when administering the lessons.

\section{ACKNOWLEDGMENT}

A sincere gratitude is addressed to all West Sumatran teachers who have willingly participated in the survey administered to accomplish this research. The researcher also thanks undergraduate students majoring in Teacher Education for Elementary School who have taken their time to complete the survey. This survey has been successfully accomplished due to the contribution from many parties.

\section{REFERENCES}

[1] Trianto. (2010). Model Pembelajaran Terpadu. Jakarta: Bumi Aksara

[2] Directorate of Primary and Secondary Education of Republic Indonesia. 2016. Panduan Pembelajaran Tematik Terpadu Sekolah Dasar. Jakarta: Kementerian Pendidikan dan Kebudayaan.

[3] Pudjiastuti, Ari. (2010). Problems in Applying Thematic Instruction in the First Grade of Elementary School. Dissertation, Instructional Technology Department, Post- Graduate Program, State University of Malang.

[4] Sinaga, S. S. (2010). Pemanfaatan Dan Pengembangan Lagu Anak-Anak Dalam Pembelajaran Tematik Pada Pendidikan Anak Usia Dini/TK. Journal of Arts Research Education, 10(1), doi: https://doi.org/10.15294/harmonia.v10i1. 55

[5] Karli, H. (2010). Penerapan Pembelajaran Tematik SD di Indonesia. EduHumaniora: Jurnal Pendidikan Dasar. 2(1), doi: http://dx.doi.org/10.17509/eh.v2i1.2752

[6] Shidik, H. A. (2018). Guru Mengajar Kurang Maksimal, Angka Siswa Tak Naik Tinggi. Kabar Madura. Retrieved from:https://kabarmadura.id/ guru-mengajar-kurang-maksimal-angka-siswa-tak- 
naik- kelas-tinggi/ on Agust $30^{\text {th }}$

[7] Amri, Sofan. 2013. Pengembangan \& Model Pembelajaran Dalam Kurikulum. 2013. Prestasi Pustakarya. Jakarta.

[8] Ardipal. (2017). Pendidikan Anak Usia Dini, dan Beberapa Aspek yang Mempengaruhinya. Solok: CV. Berkah Prima

[9] Wicaksono, Indra. (2011). Penggunaan Musik sebagai Media Pembelajaran Seni di Taman Kanak-Kanak Hj. Isriati Baiturrahman 1 Semarang. SkripsiUniversitas Negeri Semarang. Retrieved from: https://lib.unnes.ac.id/1453/

[10] Nasution, R.A. (2016). Pembelajaran Seni Musik bagi Pengembangan Kognitif Anak Usia Dini. RHAUDAH. X. (1). 11-21. ISSN: $2338-2163$

[11] Arostiyani, Devi. (2013). Pemanfaatan Lagu AnakAnak sebagai Media Pendidikan Karakter di Taman Kanak-Kanak Aisyiyah Desa Linggapura Kecamatan Tonjong, Brebes. (Skripsi, Universitas Negeri Semarang, 2013). Retrieved from: https://lib.unnes.ac.id/18661/

[12] Suheri, Eko. (2016). Pemanfaatan Lagu-Lagu Anak dalam Pembelajaran Tematik di TK IPAC Chandra Kusuma School Medan.(Skripsi, Universitas Negeri Medan, 2016). Retrieved from: http://digilib.unimed.ac.id/17095/

[13] Richards et al. (2012). Qualitative Methods $3^{\text {rd }}$ Edition .Los Angeles: Sage Publications

[14] Cohen, L., Manion, L., Morrison, K. R. B. (2018). Research Methods in Education (eight edition). Abingdon: Routledge

[15] Sammons, P. (2010). Application of mixed methods to the field of educational effectiveness research. In B. P. M. Creemers,

[16] L. Kriyakides, and P. Sammons (eds) Methodological Advances in Educational Effectiveness Research. London: Routledge Falmer.

[17] Creswell, J. W. (2014). Research Designs Qualitative, Quantitative, and Mixed Methods $4^{\text {th }}$ Edition. London: Sage Publications

[18] Dornyei, Z. (2003). Questionnaire in Second Language Research. London: Lawrence Erlbaum Associates Publishers

[19] Dornyei, Z., \& Taguchi, T. (2010). Questionnaires in Second Language Research: Construction, Administration and Processing (2nd ed.). New York: Routledge.

[20] Hobson, A. J. \& Townsend, A. (2010). Interviewing as Educational Research Method(s). Chapter Book. Retrieved from: https://www.researchgate.net/publication/287991930

[21] Dornyei. (2007). Research Methods in Applied Linguistics: Quantitative, Qualitative, and Mixed Methodologies. London: Oxford University Press

[22] Cohen's et al. (2007). Research Methods in Education. New York: Rouledge

[23] Anderson, G. \& Nancy Arsenault (1998). Fundamentals of Educational Research. Pennsylvania: Falmer Press

[24] Ardipal. (2017). Pendidikan Anak Usia Dini dan
Beberapa Aspek yang Mempengaruhinya. Solok: CV Berkah Prima

[25] Ardipal. (2016). Sekitar Teori Seni dan Seni Musik: Korelasi Seni dengan Pendidikan dan Sosial-Budaya. Solok: CV Berkah Prima 